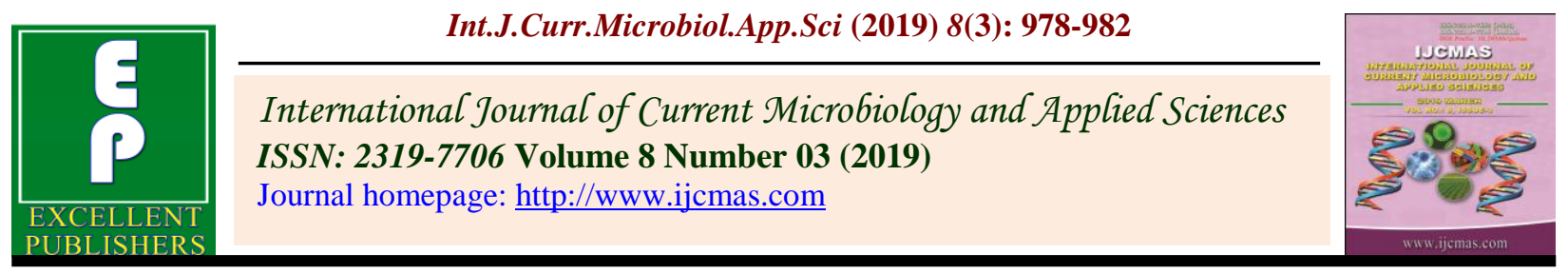

Original Research Article

https://doi.org/10.20546/ijcmas.2019.803.117

\title{
Performance of Different Parthenocarpic Cucumber (Cucumis sativus L.) Hybrids for Yield and Yield Attributing Traits under Shade Net House
}

\author{
G.V. Nagamani*, J.S. Aravinda Kumar, T.B. Manjunatha Reddy, A.M. Rajesh, H. \\ Amarananjundeswara, R.L. Raghunatha Reddy and B. Doddabasappa
}

Department of Vegetable Science College of Horticulture, Kolar- 563 103, India

*Corresponding author

\author{
A B S T R A C T
}

Keywords

Cucumber,

Parthenocarpic,

Shade net, Yield

and yield attributes

Article Info

Accepted:

10 February 2019

Available Online:

10 March 2019

\begin{abstract}
A field investigation was conducted to study the effect of shade net house on yield and yield attributes of parthenocarpic cucumber (Cucumis sativus L.) hybrids at vegetable research block, Department of Vegetable Science, College of Horticulture, Kolar during 2017-2018. The results indicated a significant difference in all the yield and yield attributing parameters studied. Among the hybrids, Defence recorded maximum fruit length $(22.00 \mathrm{~cm})$. Maximum flesh thickness $(1.57 \mathrm{~cm})$ and highest fruit diameter $(4.22$ $\mathrm{cm})$ was found in the hybrid Sargon followed by Menfis $(3.92 \mathrm{~cm})$. The hybrid Alexios are better expressed their superiority over other hybrids in terms of average fruit weight $(221.60 \mathrm{~g})$, higher fruit yield per vine $(7.70 \mathrm{~kg})$, fruit yield per meter square $\left(21.33 \mathrm{~kg} / \mathrm{m}^{2}\right)$ and fruit yield per hectare $(220.06 \mathrm{t})$.
\end{abstract}

\section{Introduction}

Cucumber (Cucumis sativus $\quad$ L.) is an important member of the family Cucurbitaceae, with a chromosome number $2 n$ $=14$, which comprises of 117 genera and 825 species in warmer parts of the world. Cucumber is truly versatile crop because of wide range of uses from salad to pickles and it is also a good source of vitamin B, C, carbohydrates, calcium, phosphorus, iodine and contains a total of 4-6 per cent of dry substances, approximately 2 per cent sugars, 1 per cent albuminous substances, 0.7 per cent cellular tissue and 0.1 per cent fat (Rana, 2008). Protected cultivation being the most efficient means to overcome climatic diversity, has the potential of fulfilling the requirements of small growers as it can increase the yield manifolds and at the same time improve the quality of the produce significantly as per the demand of the market. In the recent times, the introduction of parthenocarpic hybrids in cucumber has revolutionized its cultivation under protected cultivation in India. The cultivars have also been key factor for getting maximum yield from protected condition. These can be grown 
throughout the year in protected condition with partial shade, high humidity and moderate temperature but the research on evaluation and identification of suitable parthenocarpic hybrids under protected cultivation are needed. Keeping in view the above facts, the present experiment was carried out to find out the suitable parthenocarpic hybrids to get higher yield under shade net house condition.

\section{Materials and Methods}

The experiment was conducted under shade net house of $302.4 \mathrm{~m}^{2}$ (325) at Department of Vegetable Science, College of Horticulture, Kolar during the year 2017-18. The experiment was laid out in Randomized Complete Block Design involving 18 parthenocarpic cucumber hybrids with three replications on raised beds having dimensions of $100 \times 40 \times 50 \mathrm{~cm}$ (width, height \& distance between two beds) and plot size of about 3.6 $\mathrm{m}^{2}$. The seedlings were raised on soilless media and healthy 18-20 days old seedlings transplanted in the experimental field at a spacing of $60 \mathrm{~cm}$ between rows and $60 \mathrm{~cm}$ between plants in paired row system. For yield characters, data were recorded on five randomly selected plants in each replication and fruit characters were noted from 10 random fruits from third harvest and observations were recorded on fruit length $(\mathrm{cm})$, fruit diameter $(\mathrm{cm})$, flesh thickness $(\mathrm{cm})$, average fruit weight $(\mathrm{g})$, number fo fruits per vine, fruit yield per vine, fruit yield $/ \mathrm{m}^{2}(\mathrm{~kg})$, fruit yield per hectare (t). The recorded data were statistically analyzed at 5 per cent level of significance by following the standard process as per Panse and Sukhatme (1985).

\section{Results and Discussion}

The fruit length is the most important desired marketable and commercial character in parthenocarpic cucumber. The values of fruit length ranged from $11.07 \mathrm{~cm}$ to $22.00 \mathrm{~cm}$. The highest fruit length of $(22.00 \mathrm{~cm})$ was observed in Defense followed by Borja (21.00 $\mathrm{cm})$. While, the minimum fruit length was recorded in Shinefit $(11.07 \mathrm{~cm})$ (Table 1). Among different hybrids, significant variations in fruit length might be due to genetic nature, hormonal factor, vigour of the crop and it could be also due to favorable environmental conditions, which would have influenced availability of auxin to the developing ovary. These results are in accordance with the findings of Sujatha (2017); Kumar et al., (2017); Pragathi (2014); Soleimani et al., (2009) in cucumber. The fruit diameter was highest in Sargon $(4.22 \mathrm{~cm})$, while the lowest fruit diameter was recorded in Fadia $(2.98 \mathrm{~cm})$ (Table 1). A significant variation with respect to fruit diameter might be due to genetic nature of hybrid, hormonal factor and vigour of the crop which was similar to the findings of Hochmuth and Leon (1996); Kumar et al., (2017) and Soleimani et al., (2009) in cucumber.

Fruit size increases with increase in flesh thickness resulting into high fruit diameter and fruit weight. The flesh thickness shows significant differences among different hybrids. The hybrid Sargon $(1.57 \mathrm{~cm})$ recorded maximum flesh thickness (Table 1). However, the minimum fruit flesh thickness was recorded in Apsara $(1.12 \mathrm{~cm})$. This could be due to inherent characteristics of hybrid. These results were in line with the findings of Kengar (2011). Fruit weight is one of the key yield components which are positively associated with yield. Hence, giving reliance on fruit weight would be useful for achieving fruitful results. In the present study, the maximum average fruit weight was recorded in the hybrid Alexios (221.60 g). Whereas, minimum average fruit weight was noticed in the hybrid Shinefit $(78.27 \mathrm{~g})$. The yield of hybrid directly influenced by average fruit 
weight. The present findings are close conformity with the findings of Sujatha (2017); Pragathi (2014); Singh et al., (2012); Kumar and Verma (2012); Parashar (2016) and Tiwari and Sharma (1999) in cucumber.

The number of fruits per vine is the most important yield attributing character which ultimately determines the productivity of the crop. In the present study all the parthenocarpic hybrids of cucumber significantly varied with respect to the fruit yield per vine. Among all the hybrids highest number of fruits were harvested from the hybrid Shinefit (37.90). However, least number of fruits was harvested from the hybrid Sunstar (24.87) (Table 2). This might be due to ideal weather factors under protected condition, higher level of auxin and lower level of abscissic acid accumulation in gynoecious varieties of cucumber and more accumulation of photosynthates in leaves and its mobility to developing fruits. This ultimately favoured more fruit set. These results were in accordance with the findings of Parashar et al., (2016); Kumar et al., (2017); Cardoso and Silva (2003); Sideman (2011). The data revealed that the maximum fruit yield per vine, fruit yield per meter square and fruit yield per hectare were significantly influenced by various cultivars having a range of $7.70 \mathrm{~kg} / \mathrm{vine}, 21.33 \mathrm{~kg} / \mathrm{m}^{2}$ and $220.06 \mathrm{t} / \mathrm{ha}$, respectively. The maximum values of these traits have been reported for hybrid Alexios.

Table.1 Fruit length $(\mathrm{cm})$, fruit diameter $(\mathrm{cm})$ and flesh thickness $(\mathrm{cm})$ of parthenocarpic cucumber hybrids under shade net house

\begin{tabular}{|l|l|c|c|c|}
\hline Sl. No. & Hybrids & Fruit length $(\mathbf{c m})$ & Fruit diameter $\mathbf{( c m )}$ & Flesh thickness $\mathbf{( c m )}$ \\
\hline $\mathbf{1}$ & Apsara & 17.00 & 3.12 & 1.12 \\
\hline $\mathbf{2}$ & Deltastar & 18.03 & 3.61 & 1.38 \\
\hline $\mathbf{3}$ & Borja & 21.00 & 3.50 & 1.35 \\
\hline $\mathbf{4}$ & Defense & 22.00 & 3.20 & 1.32 \\
\hline $\mathbf{5}$ & KUK-64 & 20.10 & 3.41 & 1.24 \\
\hline $\mathbf{6}$ & Shinefit & 11.07 & 3.65 & 1.25 \\
\hline $\mathbf{7}$ & Valleystar & 15.37 & 3.54 & 1.24 \\
\hline $\mathbf{8}$ & Sargon & 17.07 & 4.22 & 1.57 \\
\hline $\mathbf{9}$ & Fadia & 15.20 & 2.98 & 1.13 \\
\hline $\mathbf{1 0}$ & Silyon & 16.50 & 3.31 & 1.33 \\
\hline $\mathbf{1 1}$ & Menfis & 16.30 & 3.92 & 1.54 \\
\hline $\mathbf{1 2}$ & Kafka & 15.63 & 3.25 & 1.25 \\
\hline $\mathbf{1 3}$ & Multistar & 15.93 & 3.40 & 1.32 \\
\hline $\mathbf{1 4}$ & Alexios & 20.80 & 3.91 & 1.56 \\
\hline $\mathbf{1 5}$ & Corinto & 19.07 & 3.56 & 1.25 \\
\hline $\mathbf{1 6}$ & KUK-53 & 17.63 & 3.61 & 1.31 \\
\hline $\mathbf{1 7}$ & Sunstar & 16.83 & 3.53 & 1.27 \\
\hline $\mathbf{1 8}$ & KPCH-1 & 16.43 & 3.43 & 1.31 \\
\hline Mean & & 17.44 & 3.51 & 0.04 \\
\hline S Em \pm & & 0.37 & 0.06 & 0.12 \\
\hline CD $(\mathbf{p}=\mathbf{0 . 0 5})$ & 1.07 & 0.16 & 5.41 \\
\hline CV $(\mathbf{\%})$ & & 3.69 & 2.82 & \\
\hline
\end{tabular}


Int.J.Curr.Microbiol.App.Sci (2019) 8(3): 978-982

Table.2 Average fruit weight (g), number of fruits per vine, Fruit yield per vine (kg), fruit yield $/ \mathrm{m}^{2}(\mathrm{~kg})$ and fruit yield/ha $(\mathrm{t})$ of parthenocarpic cucumber hybrids under shade net house

\begin{tabular}{|c|c|c|c|c|c|c|}
\hline $\begin{array}{l}\text { Sl. } \\
\text { No. }\end{array}$ & Hybrids & $\begin{array}{c}\text { Average } \\
\text { fruit weight } \\
\text { (g) }\end{array}$ & $\begin{array}{l}\text { Number of } \\
\text { fruits per } \\
\text { vine }\end{array}$ & $\begin{array}{l}\text { Fruit yield } \\
\text { per vine } \\
\text { (kg) }\end{array}$ & $\begin{array}{c}\begin{array}{c}\text { Fruit } \\
\text { yield//m² }\end{array} \\
(\mathbf{k g})\end{array}$ & $\begin{array}{c}\text { Fruit } \\
\text { yield/ha }(t)\end{array}$ \\
\hline 1 & Apsara & 150.40 & 35.07 & 5.28 & 14.64 & 150.96 \\
\hline 2 & Deltastar & 186.47 & 26.27 & 4.90 & 13.58 & 140.10 \\
\hline 3 & Borja & 201.13 & 31.70 & 6.44 & 17.85 & 184.12 \\
\hline 4 & Defense & 199.53 & 27.73 & 5.41 & 15.00 & 154.67 \\
\hline 5 & KUK-64 & 171.47 & 29.83 & 5.10 & 14.12 & 145.65 \\
\hline 6 & Shinefit & 78.27 & 37.90 & 2.97 & 8.23 & 84.84 \\
\hline 7 & Valleystar & 166.93 & 36.57 & 6.11 & 16.94 & 174.68 \\
\hline 8 & Sargon & 220.67 & 32.40 & 7.15 & 19.81 & 204.36 \\
\hline 9 & Fadia & 156.40 & 32.93 & 5.05 & 14.00 & 144.43 \\
\hline 10 & Silyon & 163.93 & 33.33 & 5.42 & 15.02 & 154.89 \\
\hline 11 & Menfis & 184.67 & 30.67 & 5.53 & 15.32 & 157.97 \\
\hline 12 & Kafka & 155.97 & 31.83 & 4.93 & 13.67 & 141.02 \\
\hline 13 & Multistar & 165.67 & 35.73 & 5.83 & 16.14 & 166.51 \\
\hline 14 & Alexios & 221.60 & 34.90 & 7.70 & 21.33 & 220.06 \\
\hline 15 & Corinto & 187.80 & 32.33 & 5.85 & 16.21 & 167.19 \\
\hline 16 & KUK-53 & 186.60 & 30.67 & 5.73 & 15.86 & 163.62 \\
\hline 17 & Sunstar & 172.77 & 24.87 & 4.29 & 11.89 & 122.69 \\
\hline 18 & KPCH-1 & 147.47 & 28.67 & 4.24 & 11.74 & 121.14 \\
\hline \multicolumn{2}{|c|}{ Mean } & 173.21 & 31.88 & 5.44 & 15.08 & 155.49 \\
\hline \multicolumn{2}{|c|}{ S Em \pm} & 12.40 & 0.59 & 0.39 & 1.12 & 11.56 \\
\hline \multicolumn{2}{|c|}{ CD $(p=0.05)$} & 35.63 & 1.70 & 1.11 & 3.22 & 33.23 \\
\hline \multicolumn{2}{|c|}{ CV (\%) } & 12.40 & 3.22 & 13.74 & 12.88 & 12.88 \\
\hline
\end{tabular}

It was due to major yield attributing characters such as number of fruits per vine, fruit length, fruit diameter and average fruit weight. It has been observed that the formation of photosynthates, their partitioning and distribution for the final sink were higher inside the shade net. The similar findings were reported by Sujatha (2017); Pragathi (2014); Hebbar et al., (2012); Parashar (2016); Premalatha et al., (2006) and Hochmuth and Leone (1996).

The results indicated a significant difference in all the yield and yield attributing parameters studied. The maximum average fruit weight was observed in the hybrid Alexios (221.60 g). However, with respect to fruit length, hybrid Defense $(22.00 \mathrm{~cm})$ was recorded highest fruit length. Whereas, maximum fruit diameter was observed in the hybrid Sargon $(4.22 \mathrm{~cm})$. The hybrid Alexios are better expressed their superiority over other hybrids in terms of average fruit weight $(221.60 \mathrm{~g})$, higher fruit yield per vine $(7.70 \mathrm{~kg})$, fruit yield per meter square $\left(21.33 \mathrm{~kg} / \mathrm{m}^{2}\right)$ and fruit yield per hectare (220.06 t).

\section{References}

Cardoso, A. I. I. and Silva, N., 2003. Evaluation of "Japanese" cucumber hybrids under protected cultivation in two sowing dates. J. Hort. Brasileira., 21 (2): 171-176.

Hebbar, S. S., Prabhakar, M., Nair, A. K. and Murthy, S., 2012. Protected cultivation of 
cucumber hybrids in a naturally ventilated polyhouses during winter. National seminar on protected cultivation of vegetables and flowers- A value chain approach. G. B. Pant Univ. Agri. Tech. Pantnagar, Uttrakhand, India. p. 46.

Hochmuth, R. C. and Leon, L. L. C., 1996. Evaluation of twelve greenhouse cucumber cultivars and two training systems over two seasons in Florida. Proc. Fla. State Hort. Soc., 109: 174-177.

Kengar, S., 2011. Performance of tomato (Solanum lycopersicum L.) hybrids under shade house condition. M. Sc. Thesis, Univ. Agric. Sci., Dharwad. p. 52.

Kumar, R. and Verma, R. B., 2012. Yield and economic evaluation of cucumber under protected structures in Bihar. National seminar on protected cultivation of vegetables and flowers- A value chain approach. G. B. Pant Univ. Agric. Tec. Pantnagar, Uttrakhand, India. p. 36.

Kumar, S., Varsha, C. I., Saravaiya, S. N. and Raj, D., 2017. Potentiality of greenhouse cucumber cultivars for economic and nutritional realization. Int. J. Farm Sci., 7(1): 1-7.

Panse, V. G. and Sukhatme, P. V., 1985. Statistical methods for agricultural workers. Indian Council of Agricultural Research, ICAR, New Delhi.

Parashar, A., Yadav, P. K., Singh, R. S. and Shukla, A. K., 2016. Effect of different protected structures on vegetative and yield attributes of cucumber under arid conditions of Rajasthan. Prog Hort., 48(1): 78-82.

Pragathi, K., 2014. Evaluation of cucumber (Cucumis sativus L.) hybrids for production potential and qualitative traits under net house conditions. M.Sc. Thesis, Department of Vegetable Science, Dr. Y. S. R. Horticultural University, Anantharajupet. pp. 1-125.

Premalatha, M. G. S., Wahundeniya. K. B., Weerakkody, W. A. P. and Wicramathunga, C. K., 2006. Plant training and spatial arrangement for yield improvements in greenhouse cucumber (Cucumis sativus L.) varieties. Trop Agri. Res., 18: 346-357.

Rana, M. K., 2008. Scientific cultivation of vegetables. Kalyani publishers. New Delhi. pp. 139.

Sideman, B., 2011. Research report:

Greenhouse cucumber variety trial, 2010. Univ. New Hampshire cooperative Extension.

Singh, D. K., Maurya, S. K., Singh. A., Singh, D. P., Sarkar, M. and Lohani, M., 2012. Assessment of parthenocarpic cucumber genotypes under protected cultivation. National seminar on protected cultivation of vegetables and flowers- A value chain approach. G. B. Pant Univ. Agric. Tech. Pantnagar, Uttrakhand, India. p.12.

Soleimani, A., Ahmadikhah, A. and Soleimani, S., 2009. Performance of different greenhouse cucumber cultivars (Cucumis sativus L.) in southern Iran. Afr. J. Biotechnol., 8(17): 4077-4083.

Sujatha., 2017. Studies on performance of parthenocarpic cucumber (Cucumis sativus L.) hybrids under naturally ventilated polyhouse. M.Sc. Thesis submitted to University of Agricultural Sciences, Dharwad.

Tiwari, G. N. and Sharma, P. K., 1999. Offseason cultivation of cucumbers in a solar greenhouse. Energy. 24:151-156.

\section{How to cite this article:}

Nagamani, G.V., J.S. Aravinda Kumar, T.B. Manjunatha Reddy, A.M. Rajesh, H. Amarananjundeswara, R.L. Raghunatha Reddy and Doddabasappa, B. 2019. Performance of Different Parthenocarpic Cucumber (Cucumis sativus L.) Hybrids for Yield and Yield Attributing Traits under Shade Net House. Int.J.Curr.Microbiol.App.Sci. 8(03): 978-982. doi: https://doi.org/10.20546/ijcmas.2019.803.117 